\title{
MORPHOLOGIC AND MOLECULAR CHARACTERIZATION OF SPECIES OF Myrciaria spp
}

\author{
PEREIRA, Márcio ${ }^{1}$ \\ OLIVEIRA, Antonio Luis $\mathrm{de}^{2}$ \\ SENA, Janete Apparecida Desidério ${ }^{3}$ \\ COSTA, Juliana Regina Vieira da ${ }^{4}$ \\ ALMEIDA, Marcílio de \\ GONÇALVES, Antonio Natal
}

Recebido em: 2009-01-26

Aprovado em: 2009-02-28

ISSUE DOI: $10.3738 / 1982.2278 .185$

SUMMARY: The jabuticaba tree is considered one of the most tipical brasilian fruit tree, however, there are a little of studies of this plant in the literature and even in the specilized literature, there are controversies about its classification many. The present work makes some comparisons between jabuticaba species, using morphologic markers (organography) and molecular markers (RAPD) technique. The morphologic characteristics of the plants, used as morphologic markers, were compared with specimens present on herbaria from São Paulo and Minas Gerais states and through the revision of specialized literature. Molecular differences between the species were identified by molecular in Piracicaba, Jaboticabal and Ituverava cities, São Paulo, Brasil. Morphologic and molecular differences between the studied plants were identified and arranged in four groups, the identified species were: Myrciaria cauliflora (Mart.) O. Berg, Myrciaria coronata Mattos, Myrciaria jaboticaba (Vell.) O. Berg., Myrciaria phytrantha (Kiaersk.) Mattos. The technique of molecular markers with the technique of morphologic markers (organography) showed to be an important tool in the identification of jabuticaba tree species.

Keywords: Myrciaria. Biological identification. Morphologic markers. Molecular markers (RAPD)

\section{CARACTERIZAÇÃO MORFOLÓGICA E MOLECULAR DE ESPÉCIES DE Myrciaria spp}

RESUMO: A Jabuticabeira é considerada como uma das fruteiras mais típicas do Brasil, contudo há poucos estudos desta planta na literatura e mesmo na literatura especializada, existem muitas controvérsias sobre sua classificação. Este trabalho faz comparações entre as espécies de Jabuticabeiras, usando as técnicas de marcadores morfológicos (Organografia) e moleculares (RAPD). As características morfológicas das plantas, usadas como marcadores morfológicos, foram comparadas com espécimes presentes nos herbários dos Estados de São Paulo e Minas Gerais e através da revisão de literatura especializada. As diferenças moleculares entre as espécies foi determinada através do uso de marcadores moleculares (RAPD). O experimento foi realizado nas cidades de Piracicaba, Jaboticabal e Ituverava, São

1 FAFRAM - Faculdade "Dr. Francisco Maeda" de Ituverava Departamento de Horticultura Rod. Jerônimo Nunes Macedo, Km 01 - 14500-000 - Ituverava, SP - Brasil. UNESP/FCVA - Depto. de Biologia Aplicada à Agropecuária, 14884-900 - Jaboticabal, SP - Brasil.

2 UNESP/FCVA - Depto. de Biologia Aplicada à Agropecuária, 14884-900 - Jaboticabal, SP Brasil.

3 USP/ESALQ - Depto. de Ciências Biológicas, C.P. 9, 13418-900 - Piracicaba, SP - Brasil.

$4 \quad$ USP/ESALQ - Depto. Ciências Florestais

* Corresponding author: fafram@feituverava.com.br 
Paulo, Brasil. Diferenças morfológicas e moleculares entre as plantas estudadas foram identificadas e as mesmas foram agrupadas em quatro grupos distintos, as espécies identificadas foram: Myrciaria cauliflora (Mart.) O. Berg, Myrciaria coronata Mattos, Myrciaria jaboticaba (Vell.) O. Berg., Myrciaria phytrantha (Kiaersk.) Mattos. A técnica de marcadores moleculares aliada à técnica de marcadores morfológicos (organografia), mostrou ser uma ferramenta importante na identificação de espécies de jabuticabeiras.

Palavras-chave: Myrciaria. Jabuticabeiras. Marcadores morfológicos. Marcadores moleculares (RAPD)

\section{INTRODUCTION}

According to Mattos (1983) the jabuticaba trees haven't always been extensively studied under the taxonomic point of view. There is a lot of confusion concerning the popular names of their fruit. Many times its vulgar name is applied to different species and even different genus, depending on the area where they are found. In that sense the vegetative sprouts play an important part in the identification of the plants, which may happen in several times of the year, but those that appear in the end of the winter and beginning of the spring are the most intense. The new foliage appears in the periphery of the plants and the color varies from light green to purplish, according to the species (DONADIO, 2000). This characteristic with the floral structures are used as a parameter to identify this species.

The identification of species and varieties has been traditionally based on the description of morphologic characteristics (external and internal) of the plants. Without a doubt that description is more restricted, being sometimes necessary the use of controlled conditions to minimize the natural variability. A great progress was the development of genetic techniques based DNA markers.

Nowadays, with the use of efficient techniques to genomic analysis, statistical methods to evaluate the obtained data and efficient sofware, the study of individuals' genetic identification and populations a good stage has been reached.

Individual organisms differ in its sequences of DNA, and that variation can be considered at the level of individual genes (genic) or genotypes (genotypical). The genetic variation that occurs in time and in space is influenced by the biology and the relationships that the individual has with the enviroment, influencing in its survival strategy. Measuring the genetic variation and applying genetic models of populations one can infer on the biology of organisms. The processes that affect the individuals, affect the population, influencing in the species and interfering in the taxonomic hierarchy (SUNNUCKS, 2000) .

According to the same author, the adapted choice of the technique for genetics- 
analysis is vital for the success in the study of the individual's molecular identification. For that study it can be used the genotypical series for study of multiple loculus, being not very accurate, they visualize many anomalous genes at the same time, but they are technically convenient. The gene variation is used for the study of unique loculus (simple), they produce more consistent data for a more precise analysis, promoting better comparability. The great usefulness of molecular techniques allows to observe differences with great resolution level, finding differences that would be identical when phenotypic characteristics are used. These differences are obtained independently from the studied part or of the conditions in which the plant was cultivated. To observe the differences of DNA in living beings it is necessary a group of appropriate techniques. Of the existent ones, the polymerase chain reaction (PCR) and its variants are the most important.

The method of amplification of fragments of DNA, RAPD, brought a true democratization of the analysis of molecular polyformism, when allowing the accomplishment of studies of genetic analysis in species previously not contemplated (WILLIAMS et al., 1993).

For the exposed, and in an attempt of contributing to the solution of the problem of jabuticaba tree identification, the present work has the objective to identify jabuticaba tree species using techniques of morphologic markers (organography) as well as molecular markers.

\section{MATERIAL AND METHODS}

To collect the botanical material used in the identification of the jabuticaba species (Myrciaria spp.), the procedure recommended by the Institute of Botany of São Paulo (Série Documentos, 1989) was used.

Thus, the collection of fertile branches of the plant was made at a height of 2.5 meters from the level of the soil in the terminal branches, always in the faces east and west.

Due to its quite fine nature, the flowers of the jabuticabeira (jabuticaba tree) were conserved in liquid of Hammarlund (copper sulfate in saturated solution + formaldehyde at $40 \%=$ formalin + distilled water in the proportion of 3:0,1:1). The present fruits in some plants were collected and conserved in solution of copper sulfate in aqueous solution at 5\%, sulfurous acid in aqueous solution at 5-6\% and glycerin 
(method of Drummond).

For each collected material, a record was filled with additional data as texture of the peel, load of the plant, size of the peduncle and of the fruit, etc, according to the orientation of the National Council of Scientific and Technological Development, this information was later on transcribed onto an herbarium record.

After the drying out the flowers in absorbent paper, they were pressed and dehydrated in stove at the Laboratory of Botany at Faculdade " Dr. Francisco Maeda " (FAFRAM). The assembly of the dried herbarium specimens was made by placing the flowers in paper bags and labels were placed in the inferior right corner of the assembly cardboard. In the left superior corner, diametrically opposite, an envelope was fastened to contain the parts which eventually fell down from the material during the dying out procedure as well as those necessarily taken for the study of the vegetable.

The collected material was identified with codes:

- The materials from the orchard of the Section of Horticulture of the Department of Vegetable Production of ESALQ-USP:

Codes: Pira1, Pira2, Pira3, E01, E02, E03, E04, P01, and P02.

- The collected materials from the orchard of the Department of Vegetable Production of ESALQ-USP, located in the Section of Engineering:

Codes: P1A, P2A, P3A, P4A, P5A, P6A, P7A, P8A, P9A, and P10A.

- The collected materials from the Section of Fruit-culture at The College " Dr. Francisco Maeda " of Ituverava-SP:

Codes: 1I, 2I, 3I, 4I, 5I, 6I, 7I, 8I, 9I, 10I, 11I and 12I.

\section{REVISION OF HERBARIA}

Considering its location and its relationship with the main areas of occurrence, the species of cultivated jabuticabeiras, the dried herbarium specimens of the collected material was compared with other specimens of the list of chosen herbaria and specialized literature.

The herbaria selected for the analysis of the dried herbarium specimens are described in Table 1. 
TABLE 1- Herbaria used for revision of the botanical material

\begin{tabular}{|c|c|c|c|c|}
\hline State & City & Sigla & Institution & Trustee \\
\hline SP & São Paulo & SP & $\begin{array}{l}\text { Instituto de Botânica de São Paulo - } \\
\text { Secretaria de Estado do Meio } \\
\text { Ambiente }\end{array}$ & $\begin{array}{l}\text { Dra Inês } \\
\text { Cordeiro }\end{array}$ \\
\hline SP & São Paulo & $\mathrm{SPB} / \mathrm{SPF}$ & $\begin{array}{l}\text { Instituto de Biociências - } \\
\text { Universidade de São Paulo }\end{array}$ & $\begin{array}{l}\text { Dr. José } \\
\text { Rubens } \\
\text { Pirani }\end{array}$ \\
\hline SP & Campinas & UEC & Universidade de Campinas & $\begin{array}{l}\text { Dr }^{\circ} \\
\text { Washington } \\
\text { Marcondes } \\
\text { Ferreira Neto }\end{array}$ \\
\hline SP & Campinas & IAC & Instituto Agronômico de Campinas & $\begin{array}{l}\text { Dra Sigrid } \\
\text { Jung } \\
\text { Mendaçolli }\end{array}$ \\
\hline SP & Rio Claro & HRCB & UNESP-Rio Claro & $\begin{array}{l}\text { Dr. Marco } \\
\text { Antônio } \\
\text { Assis }\end{array}$ \\
\hline SP & Piracicaba & ESA & ESALQ-USP/Piracicaba & $\begin{array}{l}\text { Dr. Lindolfo } \\
\text { Capellari } \\
\text { Júnior }\end{array}$ \\
\hline SP & Ituverava & FAFRAM & Faculdade "Dr. Francisco Maeda" & $\begin{array}{l}\text { M.Sc.Márcio } \\
\text { Pereira }\end{array}$ \\
\hline MG & Uberlândia & UFU & Universidade Federal de Uberlândia & $\begin{array}{l}\text { Dro Jimi } \\
\text { Nacki } \\
\text { Nakagima }\end{array}$ \\
\hline MG & $\begin{array}{c}\text { Belo } \\
\text { Horizonte }\end{array}$ & UFMG & $\begin{array}{l}\text { Universidade Federal de Minas } \\
\text { Gerais }\end{array}$ & $\begin{array}{l}\text { Dr. Júlio } \\
\text { Lombardi }\end{array}$ \\
\hline
\end{tabular}

\section{MOLECULAR CHARACTERIZATION}

Of the same plants where the vegetative and reproductive material was collected for morphologic analysis, leaves of new sprouts were collected (not totally expanded), what resulted in approximately $180 \mathrm{mg}$ of fresh tissue. This material was placed in small paper bags, properly identified with the code of the plants and stored in containers with liquid nitrogen at $-86^{\circ} \mathrm{C}$ and, soon after transported until the laboratory of Genetics of Bacteria of the Department of Applied Biology to the Agriculture of UNESP/FCAV for the extraction of the DNA.

\section{DNA EXTRACTION OF}

The extraction of DNA of the leaves of the jabuticabeiras proceeded, at first, in the method described in Lodhi et al. (1994), modified by the staff of the Laboratory of Jaboticabal-SP. 


\section{DNA QUANTIFICATION AND QUALITY}

The samples were quantified in spectrophotometer DU 640B (Beckman), diluted in the proportion of $2 \mu \mathrm{L}$ of the solution stock of DNA in $98 \mu \mathrm{L}$ of TE 10:1 (v/V).

The quantification using the spectrophotometer method allows to estimate the purity of the DNA through average of readings taken at 260 and $280 \mathrm{~nm}$. Pure preparations of DNA have values for this coefficient in the interval from 1.8 to 2.0. Values below 1.8 indicate contamination of the nucleic acid with protein. To evaluate the amount of obtained total DNA it was used the pattern where an absorbency unit at $260 \mathrm{~nm}$ is equal to $50 \mathrm{mg}$ of DNA per $\mu \mathrm{L}$ of solution. The final concentration used as work solution was of $10 \mathrm{ng}$. $\mu \mathrm{L}-1$, necessary for the reactions of RAPD.

The quality analysis of the extracted DNA was carried out in electrophoresis of agarose gels at $0.8 \%$, where it was applied $10 \mu \mathrm{L}$ of DNA of the samples and $3 \mu \mathrm{L}$ of charge buffer (Tris - HCL 0,1M, pH 6.8; blue of bromophenol 0.02\%; glycerol 50\%). To compare the pattern of the bands $8 \mu \mathrm{L}$ of " $1 \mathrm{~Kb}$ Plus DNA Ladder " of GIBCO/BRL was used. The buffer used in the prepare of electrophoresis and gel was Tris-borateEDTA 1X (Tris 89 mM; H3BO3 mM; EDTA 2.5 mM, pH 8.2) containing 0.5 mg. $\mu \mathrm{L}-1$ of ethyl bromide. The electrophoresis time was of approximately $2 \mathrm{~h}$ in tension of $48 \mathrm{~V}$. The fragments of genomic DNA were visualized under light UV and documented in a photodocumentator model GEL DOC 2000 (BIO RAD).

\section{DNA AMPLIFICATION}

DNA samples were amplified in the Laboratory of Jaboticabal-SP.

The procedure for reactions of amplifications of the DNA, as well as the analysis of PCR with adopted primers, was the same as described by Williams et al. (1990). The primers used in this work came from the collection of the University of British Columbia - Nucleic Acid - Protein Service Unit (Canada), whose access numbers to the collection, as well as the respective sequences, are described in the Table 2. 
TABLE 2 - Arbitrary sequences of the initiators used and respective

\begin{tabular}{llll}
\hline 201. & CTG GGG ATT T & 226. & GGG CCT CTA T \\
202. & GAG CAC TTA C & 227. & CTA GAG GTC C \\
203. & CAC GGC GAG T & 228. & GCT GGG CCG A \\
204. & TTC GGG CCG T & 230. & CGT CGC CCA T \\
205. & CGG TTT GGA A & 231. & AGG GAG TTC C \\
206. & GAG GAC GTC C & 232. & CGG TGA CAT C \\
208. & ACG GCC GAC C & 233. & CTA TGC GCG C \\
209. & TGC ACT GGA G & 234. & TCC ACG GAC G \\
212. & GCT GCG TGA C & 235. & CTG AGG CAA A \\
213. & CAG CGA ACT A & 236. & ATC GTA CGT G \\
218. CTC AGC CCA G & 247. & TAC CGA CGG A \\
219. & GTG ACC TCA G & 248. & GAG TAA GCG G \\
220. GTC GAT GTC G & 279. & AGA CAT TAG A \\
223. GAT CCA TTG C & 286. & CGG AGC CGG C \\
225. & CGA CTC ACA G & 296. & CCG CTG GGA G \\
\hline
\end{tabular}

The amplification reactions were made in a volume of reaction of $20 \mu \mathrm{L}$ containing: $30 \mathrm{ng}$ of the DNA to be amplified; solution of dNTPs $2.0 \mathrm{mM} ; 1 \mathrm{mM}$ $\mathrm{MgCl} 2$; solution lid (1X); $15 \mathrm{ng}$ of each one of the initiators; $1.0 \mathrm{U}$ Taq DNA polimerase and distilled water degree Milli Q (previously sterilized).

The amplification reactions were accomplished using a thermocycler MJ Research, model PTC 100, equipped with circuit "Hot Bonnet". The program adopted for this stage of analysis was set up as described: 4 minutes at $92^{\circ} \mathrm{C}$ and, later 48 cycles of 1 minute were accomplished at $92^{\circ} \mathrm{C} ; 1$ minute and 30 seconds at $37^{\circ} \mathrm{C} ; 1$ minute and 30 seconds at $72^{\circ} \mathrm{C}$; and, in the end, 5 minutes at $72^{\circ} \mathrm{C}$.

The amplified samples were analyzed in agarose gel $1.5 \%(\mathrm{p} / \mathrm{p})$, using lid TEB 1X (89 mM of Tris; $2.5 \mathrm{mM}$ of EDTA and $89 \mathrm{mM}$ of Boric Acid, pH 8.3) containing $0.5 \mu \mathrm{g} . \mathrm{L}^{-1}$ of ethyl bromate.

The fragments amplified by PCR and separated by electrophoresis were compared with those of the DNA of known molecular weight ("1 Kb ladder") and it was verified the absence or the presence of electrophoretic migration of the same ones as well as their distances.

\section{RESULTS AND DISCUSSION}

\section{MORPHOLOGIC CHARACTERIZATION}

By means of the comparison of the collected specimens, both the description of 
the specialized bibliography, Mattos (1983), and the specimens conserved in the visited herbaria, it was possible to group the studied plants in four species, allowing to verify from the taxonomic point of view that the species of jabuticabeiras are not very studied, because from all the consulted collections just two species were found in the dried herbarium specimens, Myrciaria jaboticaba and Myrciaria cauliflora, being nonexistent dried herbarium specimens of the other species (M. coronata, M. phitrantha, M. piruviana, M. oblongata, M. spiritosantensis, M. grandiflora, and M. aureana) in the herbaria visited.

Through that research it can also be verified that the collections present vast material of the gender Myrciaria, however the species of described Jabuticabeiras are restricted to 2 groups in the herbaria of the State of São Paulo, showing that other tools should be used to aid in the identification of those species.

Of the thirty-one plants studied, the one of code Pira 1, initially identified as Myrciaria by the field employees of Piracicaba-SP, it was later identified how the genus Psidium. It is an interesting fact that justifies the difficulty and confusion concerning the vulgar names given to the fruits of the species belonging to the gender Myrciaria. Even some herbaria bring in their older collections of Mirciariae, some jabuticabeiras with different classifications, mainly between the species Myrciaria cauliflora and Myrciaria jaboticaba.

In literature itself this confusion can be noticed. Mendonça (2000), in a work developed in the jabuticabeiras collection belonging of Viçosa-MG, classified Myrciaria cauliflora (Mart.) O. Berg. as Cultivar Açú and Myrciaria jaboticaba (Vell.) O. Berg as Cultivar Sabará. Pio Corrêa (1984), in the classic dictionary of the useful plants of Brazil, classified Myrciaria jaboticaba as Cultivar Açú and Myrciaria trunciflora O. Berg. as belonging to the species Cultivar Sabará. Still in the same work the species Myrciaria cauliflora (included in the gender Eugênia) is treated like "common" or "true" Jaboticaba, having as synonymous jabuticaba of Sabará or jabuticaba of São Paulo.

In the Table 3, the 31 studied plants and their respective identifications are presented, accomplished through the comparison with the specimens of the visited herbaria visited and of the specialized literature. 
TABLE 3. Relationship of the species of identified jabuticabeiras, through the comparison of present dried herbarium specimens in the visited herbaria and in the consultation of specialized bibliography

\begin{aligned} \hline Code & \multicolumn{1}{c}{ Species } \\ \hline Pira 1 & Psidium spp \\ Pira 2 & Myrciaria jaboticaba (Vell.) O. Berg \\ Pira 3 & Myrciaria cauliflora (Mart.) O. Berg \\ 1I & Myrciaria jaboticaba (Vell.) O. Berg \\ 2I & Myrciaria cauliflora (Mart.) O. Berg \\ 3I & Myrciaria coronata Mattos \\ 4I & Myrciaria coronata Mattos \\ 5I & Myrciaria coronata Mattos \\ 6I & Myrciaria cauliflora (Mart.) O. Berg \\ 7I & Myrciaria cauliflora (Mart.) O. Berg \\ 8I & Myrciaria cauliflora (Mart.) O. Berg \\ 9I & Myrciaria jaboticaba (Vell.) O. Berg \\ 10I & Myrciaria jaboticaba (Vell.) O. Berg \\ 11I & Myrciaria cauliflora (Mart.) O. Berg \\ 12I & Myrciaria cauliflora (Mart.) O. Berg \\ P01 & Myrciaria jaboticaba (Vell.) O. Berg \\ P02 & Myrciaria jaboticaba (Vell.) O. Berg \\ P1A & Myrciaria jaboticaba (Vell.) O. Berg \\ P2A & Myrciaria jaboticaba (Vell.) O. Berg \\ P3A & Myrciaria jaboticaba (Vell.) O. Berg \\ P4A & Myrciaria jaboticaba (Vell.) O. Berg \\ P5A & Myrciaria jaboticaba (Vell.) O. Berg \\ P6A & Myrciaria jaboticaba (Vell.) O. Berg \\ P7A & Myrciaria jaboticaba (Vell.) O. Berg \\ P8A & Myrciaria jaboticaba (Vell.) O. Berg \\ P9A & Myrciaria jaboticaba (Vell.) O. Berg \\ P10A & Myrciaria jaboticaba (Vell.) O. Berg \\ E01 & Myrciaria phitrantha (Kiaersk.) Mattos \\ E02 & Myrciaria cauliflora (Mart.) O. Berg \\ E03 & Myrciaria jaboticaba (Vell.) O. Berg \\ E04 & Myrciaria jaboticaba (Vell.) O. Berg \\ \hline & \end{aligned}

\section{MORPHOLOGIC IDENTIFICATION}

The specimens belonging to the species Myrciaria jaboticaba (Vell.) O. Berg (Figure 1), presented the bicarpel ovary, infra-axillary placentation, pilose on the base, style surpassing the stamens, captured stigma, numerous stamens, flat terminal branches, green superior surface of leaves and lighter green coloring on the inferior surface, pentamerous actinomorphe corolla, and globular fruits with diameter of 1.6 to $2.2 \mathrm{~cm}$, smooth and black when ripe, and from one to four seeds in its interior. These characteristics are in agreement with the descriptions of Mattos (1983). 


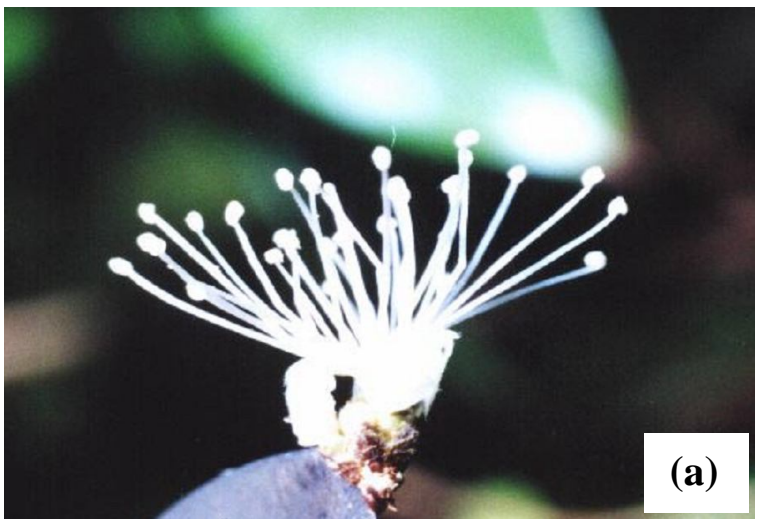

FIGURE 1 -Myrciaria jaboticaba(a) detail of flower; (b) branches with ripe fruit

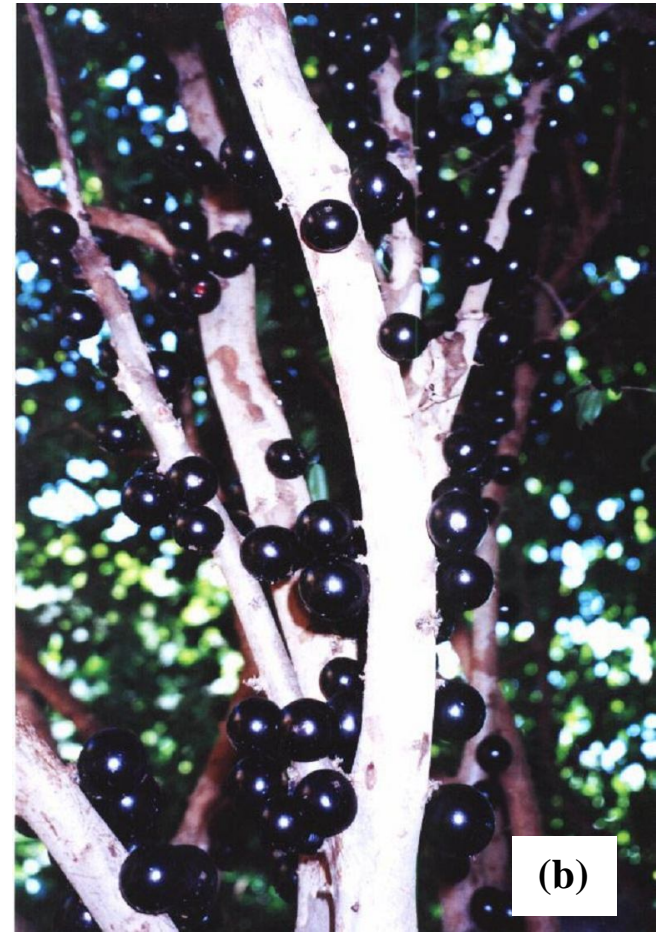

(b)

The species Myrciaria cauliflora (Mart.) O. Berg (Figure 2), presented bicarpel ovary, infra-axillary placentation, glabrous, style of $6 \mathrm{~mm}$ in length, peltade stigma, flat terminal branches and leaves with central nervure slightly printed in the superior surface and salient epidermis in to inferior surface, pentamerous actinomorphe corolla, glabrous floral button, globular fruit of 2.2 to $2.8 \mathrm{~cm}$ of length and 2.2 to $2.9 \mathrm{~cm}$ of diameter.

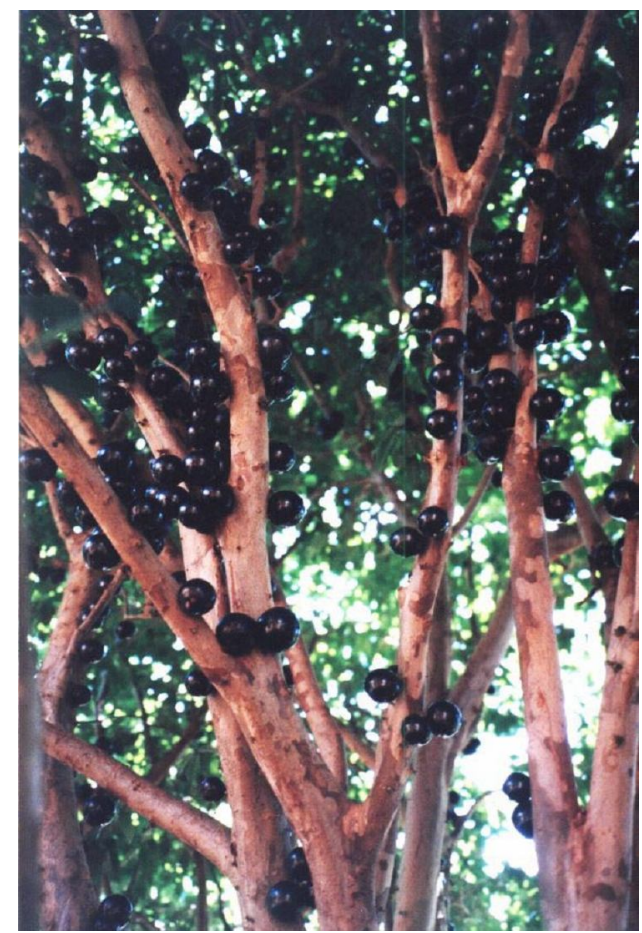

FIGURE 2 - Myrciaria cauliflora - Branches with ripe fruit 
The Myrciaria phitrantha (Kiaersk.) Mattos (Figure 3), presents bicarpel ovary, infra-axillary placentation, long and glabrous style, pentamerous actinomorphe corolla, big fruit (from 3 to $4 \mathrm{~cm}$ in diameter) with the "neck" and big leaves as main characteristic (more than twice the size of the other studied species) and pendants.

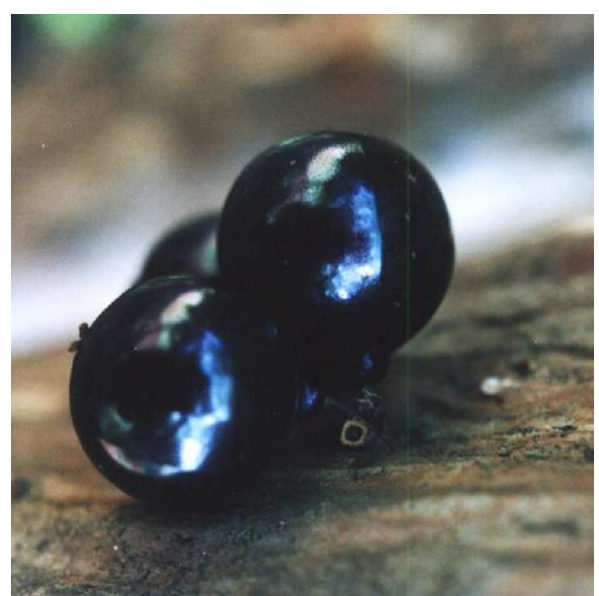

FIGURE 3 - Myrciaria phitrantha (Kiaersk.) Mattos - Detail of fruits

The specimens of the species Myrciaria coronata presented a captured stigma, bicarpel sericeous ovary, with axillary placentation, flat and grizzly terminal branches, leaf with main nervure printed in the superior surface and salient in the inferior surface, globular fruit and whitish contour of the disk of the apex.

\section{MOLECULAR CHARACTERIZATION}

In the analysis of markers RAPD, the 11 selected primers generated 45 polymorphic bands. The more polymorphic primers were the ones of number 203 and 226 (Figures 4 and 5), being the ones that also presented better image in the agarose gels. According to Colombo (1998), 10 to 30 primers, generating 50 to 100 polymorphic bands are enough to estimate genetic relationships intra and interspecies. 


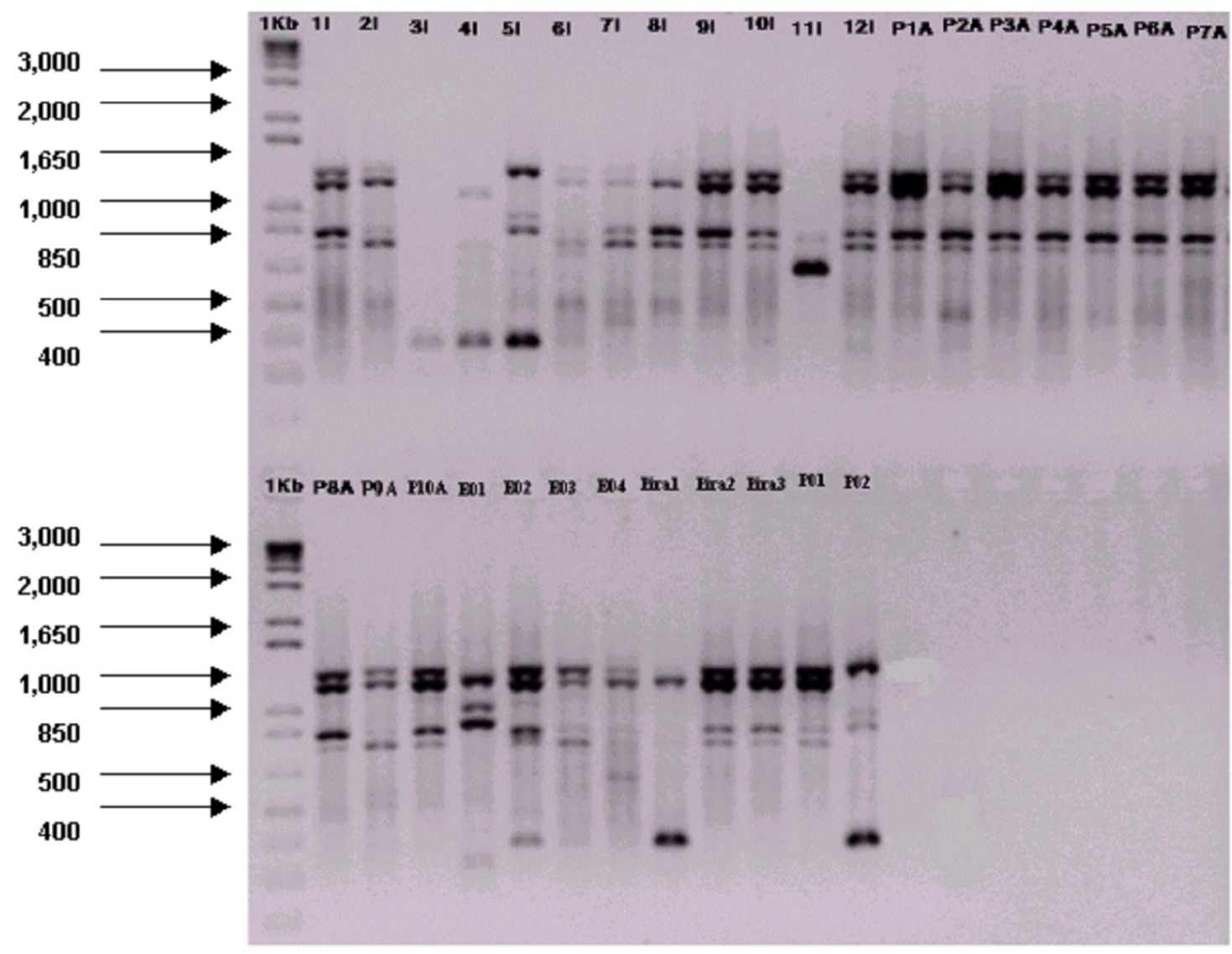

FIGURE 4 - Electrophorogram of the plants amplified with primer of number 203, being: $\mathrm{MM}=$ " $1 \mathrm{~Kb}$ Plus DNA Ladder ". 


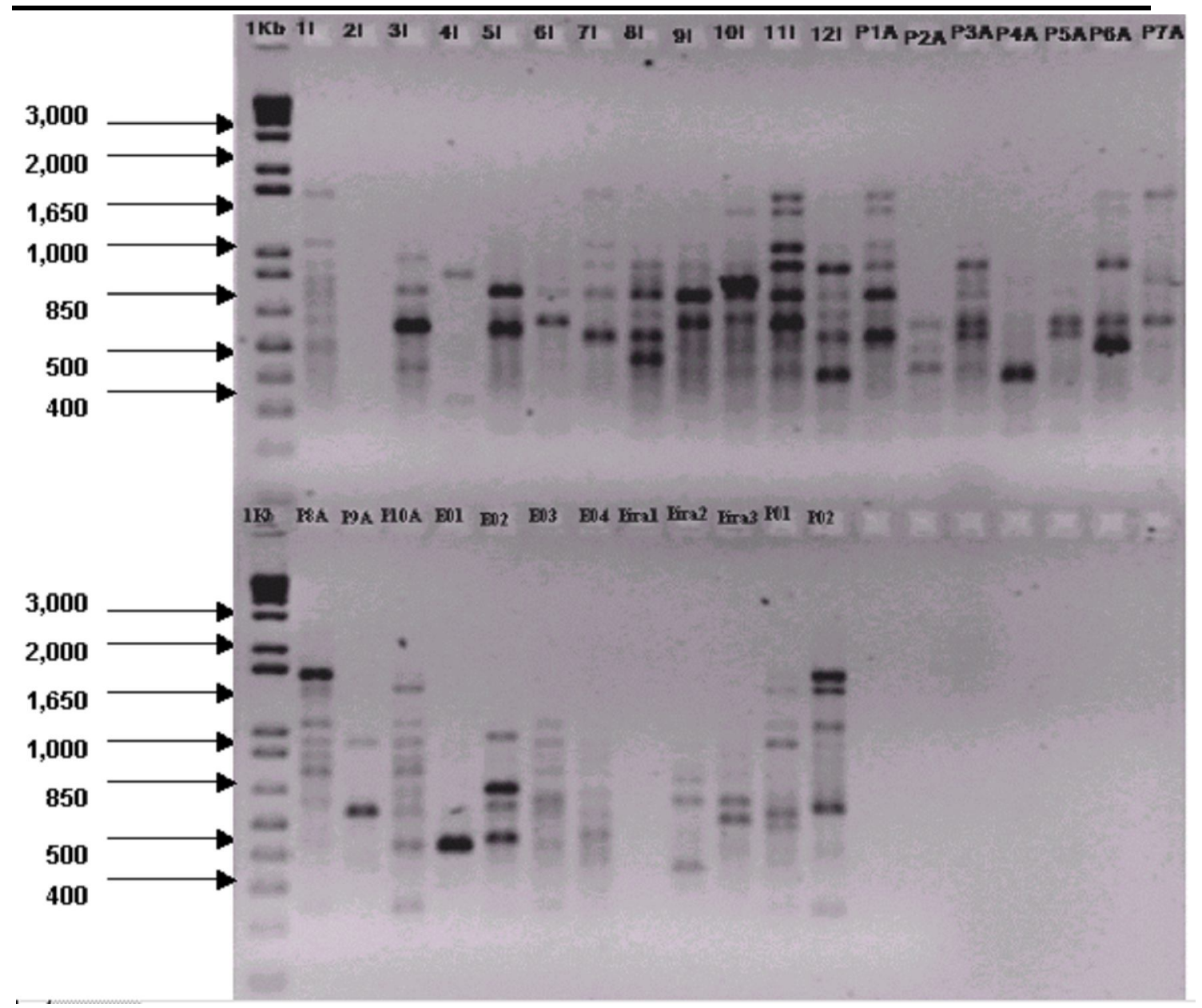

FIGURE 5 - Electrophorogram of the plants amplified with primer of number 226, being: $\mathrm{MM}=$ " $1 \mathrm{~Kb}$ Plus DNA Ladder ".

Ashburner et al. (1996) observed that the markers of type " RAPD " were capable for differentiating the coconut populations (Coco nucifera L.) coming from the Islands Rennel of those originating from of the continent. Those facts prove that the methodology of the molecular markers applied in the individuals' identification can be a tool to aid in the individuals' grouping for their genetic similarity. 


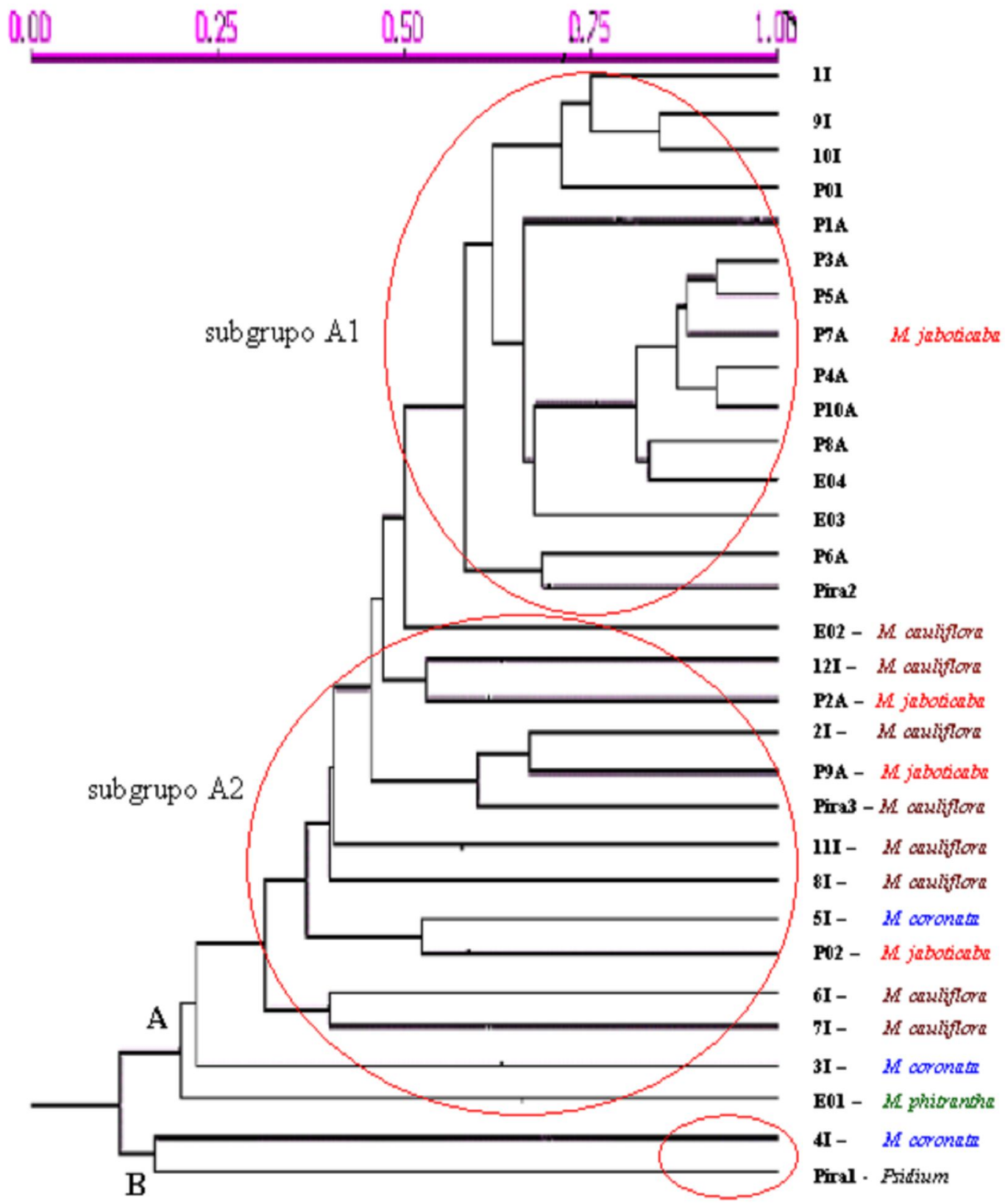

FIGURE 6 - Phylogenic diagram of genetic similarity among jabuticabeiras individuals, obtained through the coefficient of Jacard.

In Figure 6 the formation of two main groups is observed: A and B. In group B represents just two plants, whose genetic distance is approximately of $80 \%$. The plant of code " 4I " is morphologically classified, whose species is Myrciaria coronata Mattos and the plant of code " Pira 1 ", after having been collected like a Myrciaria was identified as belonging to the family of Myrtaceae, but of the gender Psidium spp.), confirming, this way, such divergence among them. 
In group A are distributed other species (M. jaboticaba, M.cauliflora, and M. phitrantha). Inside this same group, the formation of a sub group is observed (A1), where are the plants of the species $M$. jaboticaba, with a similarity degree varying from $60 \%$ to $90 \%$.

Another sub group (A2) was formed with species of $M$. cauliflora, $M$. coronata, and $M$. jaboticaba, with degrees of non similarity from $80 \%$ to $30 \%$, however, with very close genetic characteristics.

The species $M$. phitrantha Mattos, presents a genetic divergence of $80 \%$ to the other species. It can be observed in the phylogeny diagram in an isolated branch of the other groups.

In this context, it is concluded that technical RAPD-PCR, didn't allow the grouping of the plants at the species level, but it allowed to analyze, by means of generated phylogeny diagram, the degrees of genetic similarity among them, observing that, the species $M$. phitrantha was farther distant to the other species, as well as the plant identified as Psidium spp., initially collected like Myrciaria, which also had high non similarity degree, checking the reliability of this technique.

At first, if one observes the phylogeny diagram, one may infer that the markers RAPD didn't allow the grouping of the plants, according to sub group A2. However, for the accomplished study, there aren't subsidies to affirm such fact, because the studied material was compared with older collections of Myrciariae, in which there are different classifications, mainly between $M$. cauliflora and $M$. jaboticaba, proving the analysis of the sub group A2, in which most of the contained plants belongs the species $M$. cauliflora and, in which are present the plants P2A, P9A, and P02 morphologically classified as M. jaboticaba.

Concerning the species M. coronata (3I, 4I, and 5I), whose morphologic classification was just based in the Literature (Mattos, 1983), without dried herbarium specimens of this species in the visited herbaria, a more meticulous research is suggested, because those plants can present a different classification.

It is evident in phylogeny diagram that the largest genetic distances involve the plants of sub group A2, confirming the difficulty of a current morphologic classification.

Nowadays, with the use of molecular tools, it could be suggested a revision of the classification of the gender Myrciaria, as well as of the dried herbarium specimens deposited in the visited herbaria. 


\section{REFERENCES}

ASHBURNER, G.R.; THOMPSON, W.K.; HALLORAN, G.M. RAPD analysis of south pacific coconut palm populations. Crop Science, v.37, p.992-997, 1997.

COLOMBO, C. Genetic diversity characterization of casava cultivars (Manihot esculenta Crantz) with RAPD markers. Genetics and Molecular Biology, Ribeirão Preto, v.21, 1, p.105-113, 1998

DONADIO, L. C. Jaboticaba (Myrciaria jaboticaba (Vell.) Berg). Jaboticabal: FUNEP, 2000, 55p.

FERREIRA, M.E; GRATTAPAGLIA, D. Introdução ao uso de marcadores em análise genética. 2.ed. Brasília: EMBRAPA-CENARGEM, 1995. p.220 (Documento, 20)

LODHI, M.A.; YE, N.G.; WEEDEN, N.F. A simple and efficient method for DNA extraction from grapevine cultivars and Vitis species. Plant Molecular Biology Reporter v. 12: p6-13, 1994.

MATTOS, J.L.R. Fruteiras nativas do Brasil: jaboticabeiras. Porto Alegre: Nobel, 1983. 92p.

MENDONÇA, R.M.N. Maturação, secagem e armazenamento de sementes e propagação vegetativa de Jabuticabeiras (Myrciaria sp). Viçosa, 2000. 136p. (Tese de Doutorado). Universidade Federal de Viçosa.

PIO CORRÊA, M. Dicionário das plantas úteis do Brasil e das exóticas cultivadas. Rio de Janeiro: IBDF, 1984, v.4, 450p.

SÉRIE DOCUMENTOS. Técnicas de coleta, preservação e herborização de material botânico. Instituto de Botânica. São Paulo, 1989. 62p.

SUNNUCKS P. Efficient genetic markers for population biology. TREE, v 15, n.5, 2000, p.199-203.

WILLIAMS, J.G.K., KUBELIK, A.R.; LIVAK, K.J J.A. DNA polymorfims amplified by arbitrary primers useful as genetic markers. Nucleic Acids Research, v.18, p.65316535, 1990.

WILLIAMS, J.G.K.; RAFALSKI, J.A. ; TINGEY, S.V. 1993. Genetic analyss using RAPD markers. Methods in Enzymology, v.218, p.704-740, 1993. 